\title{
Growth parameters and plant biomass of tomato evaluated under different concentrations of boric acid
}

\section{Ezekiel Dare Olowolaju*, Akinjide Moses Afolabi, Abiodun Mutairu Adejumo and Kehinde Adesegun Momodu}

Department of Botany, Faculty of Science, Obafemi Awolowo University, Ile-Ife, Nigeria

*Corresponding Author: barenleezekiel86@gmail.com

\begin{abstract}
The objective of this study was to investigate the growth parameters and plant biomass of tomato (Solanum lycopesicum) evaluated under different levels of boric acid, major source of boron. The treatments were; Normal nutrient solution (control, boric acid conc. $=0.000308 \mathrm{~g} \mathrm{l}^{-1}$ ); nutrient solution in which the concentration of boric acid increased by the factor of 5 (boric acid $\times 5$, boric acid conc. $=0.00154 \mathrm{~g} \mathrm{l}^{-1}$ ); and nutrient solution in which the concentration of boric acid was increased by the factor of 10 (boric acidx10, boric acid conc. $=0.00308 \mathrm{~g} \mathrm{l}^{-1}$ ). Morphological attributes determined were shoot height, number of leaves, leaf area, shoot, leaf and root fresh and dry weight, and growth indices. Shoot height, number of leaves, leaf area, shoot, leaf and root fresh and dry weight, and growth indices in the seedlings treated with boric acid increased by factor of 10 (boric acid x10)were greater than other treatments. It can be concluded that nutrient solution of boric acid increased by a factor of ten improve the growth parameters and plant biomass of tomato.
\end{abstract}

Keywords: Dry weight, Fresh weight, Growth, Indices, Solanum lycopersicum.

\section{INTRODUCTION}

Boric acid is a major source of boron and is employed for plant cultivation around the world. Boric acid constitutes 5$20 \%$ of nutrient solutions used in various areas of agriculture, namely plant physiology and environmental science, because of the roles it plays (Türkmen et al., 2004). Boric acid along with other sources of mineral elements improves soil fertility and increase the availability of nutrient elements by holding them as mineral surfaces for plant growth and development (El-Sharkawy \& Adel-Razzak, 2010).

Optimum boron requirement can differ from one soil and one plant to another (Marschner et al., 1995). Studies on the positive and negative effects of boron on tomato have indicated the importance and significance of this mineral element independently from other nutrients on the growth and yield of tomato. Many researchers have stated that boric acid application-major source of boron lead to remarkable increment on tomato fruit quality and production (Prasad et al., 1997; Oyinlola \& Chude, 2004; Naz et al., 2012). However none of these studies have developed into the required amounts of boron needed for growth for better yield. Therefore, there is need to evaluate the optimum requirement of boron on the growth parameters, plant biomass and growth indices of of tomato. Hence, this study was conducted to assess growth and yield of tomato as affected by different concentrations of boric acid.

\section{MATERIALS AND METHODS}

\section{Experimental plant}

The Seeds of tomato (Solanum lycopersicum L.) variety Rio Grande, were utilized in this experiment. The seeds were collected from National Horticultural Research Institute (NIHORT) Ibadan, Oyo state, Nigeria.

\section{Preparation of nutrients solution}

The nutrient solution was prepared in accordance with the modified Long Ashton formula as shown in table 1.

\section{Raising of seedlings}

The seedlings of tomato were raised under a screenhouse to minimise extraneous factors such as pests, insects and water other than the quantity required. Twenty four planting bags (of about $4 \mathrm{~cm}$ in diameter and $5 \mathrm{~cm}$ in height) were obtained. The planting bags were perforated by the side and bottom to allow for proper drainage of water. The planting bags were then filled with $10 \mathrm{~kg}$ of collected soil. The seedlings of tomato were then sown at a depth of about $3 \mathrm{~cm}$ below the soil. The bags were then supplied with $200 \mathrm{ml}$ tap water daily until the seedlings were fully established. Sampling was carried out the first day of sowing. This was recorded as zero day of the experiment. Thereafter, the seedlings were made to receive $200 \mathrm{ml}$ of nutrient solution, which was further done at 3-day interval. Sampling was 
further carried out 7-day interval. The seedlings were divided into three regimes which are; Control= seedlings which were supplied with $200 \mathrm{ml}$ of normal nutrient solution, boric acid conc. $=0.000308 \mathrm{~g} \mathrm{l}^{-1}$; boric acid $\times 5=$ seedlings which were supplied with $200 \mathrm{ml}$ of nutrient solution of boric acid increased by a factor of 5 , boric acid conc. $=0.00154 \mathrm{~g} \mathrm{l}^{-1}$; boricx $10=$ seedlings which were supplied with $200 \mathrm{ml}$ of nutrient solution of boric acid increased by a factor of 10 , boric acid conc. $=0.00308 \mathrm{~g} \mathrm{l}^{-1}$. An experiment laid out in a Completely Randomized Design (CRD) with four replicates was used.

Table 1. The composition of nutrient solution.

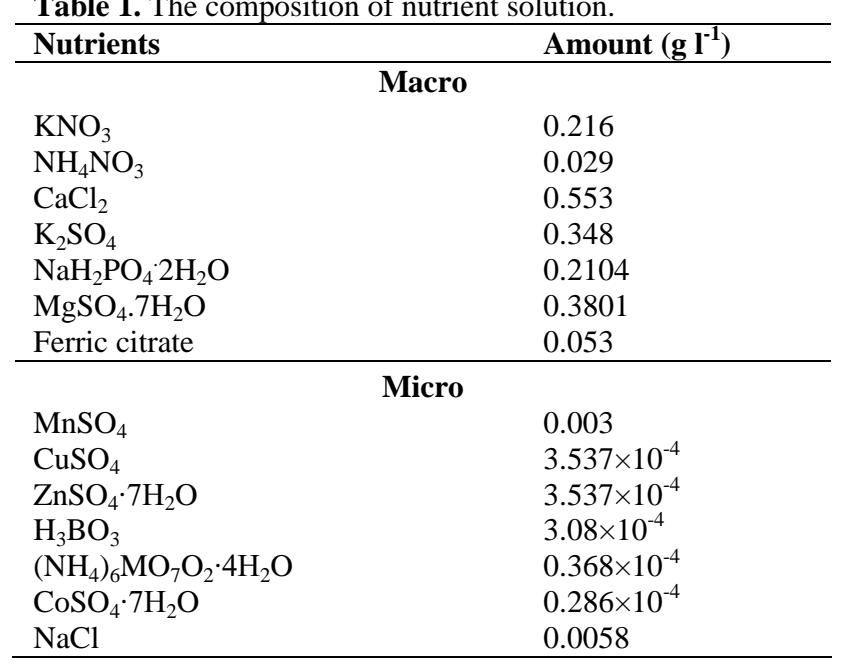

\section{Measurement of growth parameters}

Sampling was carried out at 7-day after seeding establishments. Measurements of the following morphological parameters were taken;

Shoot height: The shoot height from the randomly selected seedlings from each regimes were measured from above the soil level to the tip of the youngest leaves in the shoot apex with the aid of metre rule calibrated in centimetres.

Number of leaves: Number of leaves from randomly selected seedlings from each regimes were counted manually.

Length of internodes: The length of internodes of the first two internodes (distance between two successive nodes) was determined with the aid of metre rule calibrated in centimetres.

Number of branches: Number of branches from randomly selected seedlings from each regimes were counted manually.

Leaf length and width: The leaf length was measured from the leaf petiole to the tip of the leaf blade. The widest area of the leaf blade was measured as the leaf width. These were done with the aid of metre rule calibrated in centimetres. The values obtained from the leaf length and width were used to determined the leaf area as follows:

$$
\text { Leaf area }=\text { Leaf length } \times \text { Leaf width } \times \text { Correction Factor }(0.75)
$$

\section{Growth indices}

Crop growth rate (CGR), relative growth rate (RGR), leaf area index (LAI), net assimilation rate (NAR), leaf area ratio (LAR), tissue water contents (TWC) were determined according to Olowolaju \& Adelusi (2017) using leaf area and dry matter data.

$$
\begin{gathered}
\text { Crop growth rate }(\mathrm{CGR})=\frac{\mathrm{W} 2-\mathrm{W} 1}{\mathrm{t} 2-\mathrm{t} 1} \\
\text { Relative growth rate }(\mathrm{RGR})=\mathrm{NAR} \times \mathrm{LAR} \\
\text { Net assimilation rate }(\mathrm{NAR})=\frac{(\mathrm{W} 2-\mathrm{W} 1) \times(\ln \mathrm{A} 2-\ln \mathrm{A} 1)}{(\mathrm{A} 2-\mathrm{A} 1) \times(\mathrm{t} 2-\mathrm{t} 1)} \\
\text { leaf area ratio }(\mathrm{LAR})=\frac{(\mathrm{A} 2-\mathrm{A} 1) \times(\ln \mathrm{W} 2-\ln \mathrm{W} 1)}{(\mathrm{W} 2-\mathrm{W} 1) \times(\ln \mathrm{A} 2-\ln \mathrm{A} 1)} \\
\text { Tissue water contents }(\mathrm{TWC})=\frac{\text { Fresh weight }- \text { dry weight }}{\text { fresh weight }} \times 100
\end{gathered}
$$




\section{Plant biomass}

Determination of fresh weight: The leaf, root and shoot fresh weight were determined by weighing the leaf, root and shoot from the respective with the aid of a weighing balance.

Determination of dry weight: The tomato plants were harvested from the respective treatments. The leaf, root and shoot were separated from the main the plant, and thereafter oven dried in a Gallenkhamp oven at $45^{\circ} \mathrm{C}$ for 72 hours. The leaf, root and shoot were then weighed with a weighing balance.

\section{RESULTS}

\section{Growth parameters}

Shoot height of tomato increased over time for all treatments (Fig. 1). The plants treated with boric acid increased by a factor of 10 (boric acid $\times 10$ ) were tallest at 10 WAS followed by the boric acid $\times 5$ and control treatments. The separation point for the control and other treatments was around 8 WAS.

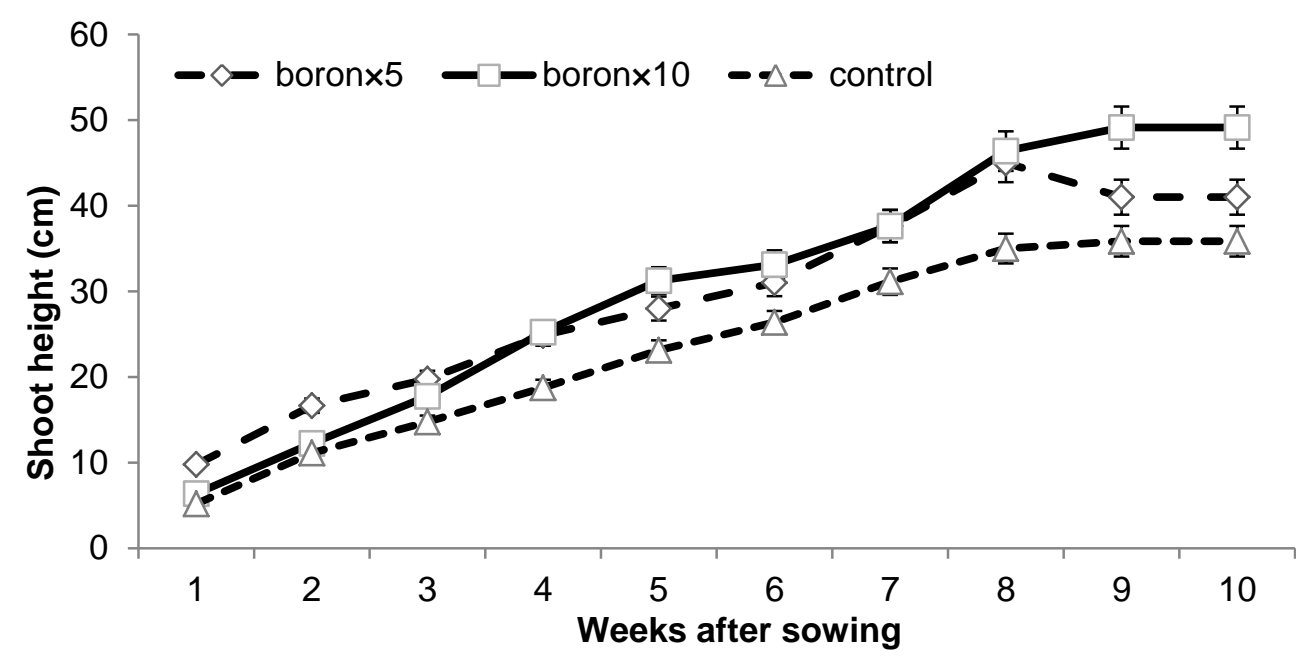

Figure 1. Effect of different levels of boric acid on the shoot height of tomato. [Boric acid $\mathrm{x} 5=$ Boric acid increase by a factor of 5; Boric acid conc. $=0.00154 \mathrm{~g} \mathrm{l}^{-1}$; Boric acid $\mathrm{x} 10=$ Boric acid increase by a factor of 10 ; Boric acid conc. $=0.00308 \mathrm{~g} \mathrm{l}^{-1}$; Control $=$ Normal nutrient solution; Boric acid conc. $=0.000308 \mathrm{~g} \mathrm{l}^{-1}$ ]

Numbers of leaves increased over time for all treatments (Fig. 2). Plants receiving boric acid $\times 5$ and boric acid $\times 10$ treatments had more leaves than the control at 10 WAS. The separation point for the control and other treatments was around 4 WAS.

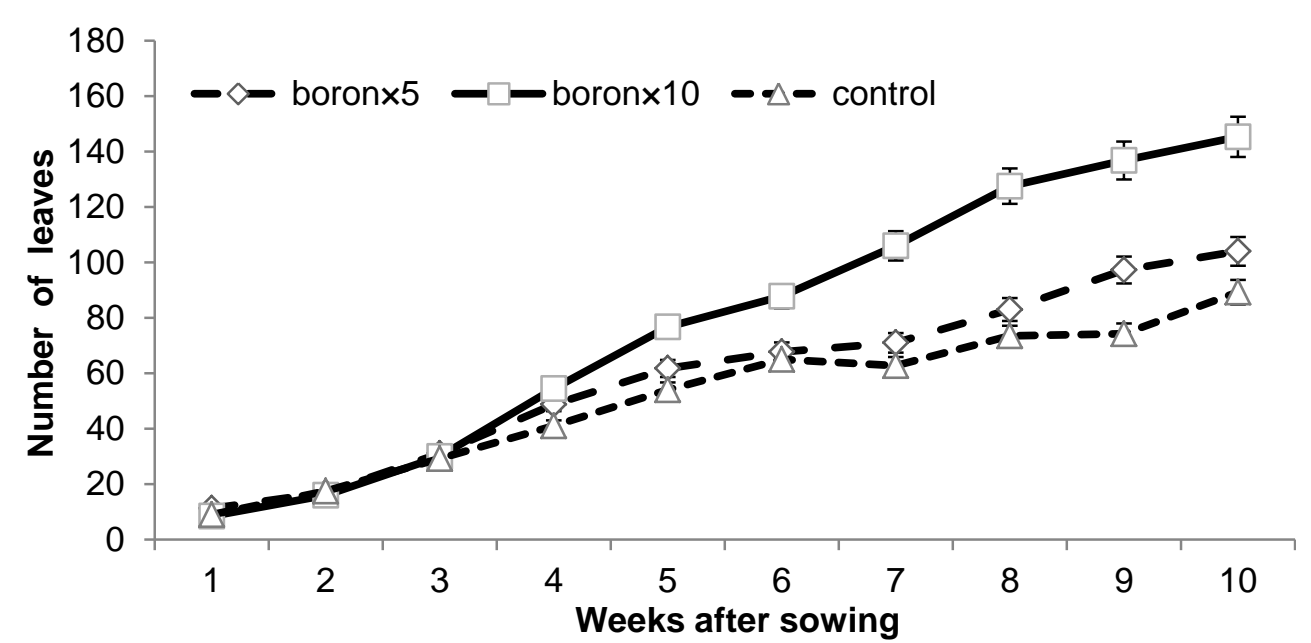

Figure 2. Effect of different levels of boric acid on the number of leaves of tomato. [Boric acid $\mathrm{x} 5=$ Boric acid increase by a factor of 5; Boric acid conc. $=0.00154 \mathrm{~g} \mathrm{l}^{-1}$; Boric acid $\times 10=$ Boric acid increase by a factor of 10 ; Boric acid conc. $=0.00308 \mathrm{~g} \mathrm{l}^{-1}$; Control $=$ Normal nutrient solution; Boric acid conc. $=0.000308 \mathrm{~g} \mathrm{l}^{-1}$ ]

Internode length increased over time for boric acid treatments. Plants receiving boric acid $\times 10$ treatment had longer internodes at 10 WAS. The control plants had the shortest internodes, and the plants receiving boric acid $\times 5$ was intermediate. The separation point for boron $\times 10$ treatment was around 7 WAS. Internode length increased over time for all treatments (Fig. 3). Number of branch increased over time for boric acid treatments.

Plants receiving boric acid $\times 10$ treatment had highest number of branch at $10 \mathrm{WAS}$. The control plants had the lowest, and the plants receiving boric acid $\times 5$ was intermediate. The separation point for boron $\times 10$ treatment was around 
7 WAS. Number of branch increased over time for all treatments (Fig. 4).

Leaf area increased over time for all treatments (Fig. 5). Plants receiving boron $\times 10$ treatment had highest leaf area at 10 WAS. The control plants had the lowest, and the plants receiving boron $\times 5$ was intermediate. The separation point for boric acid $\times 10$ treatment was around 4 WAS.

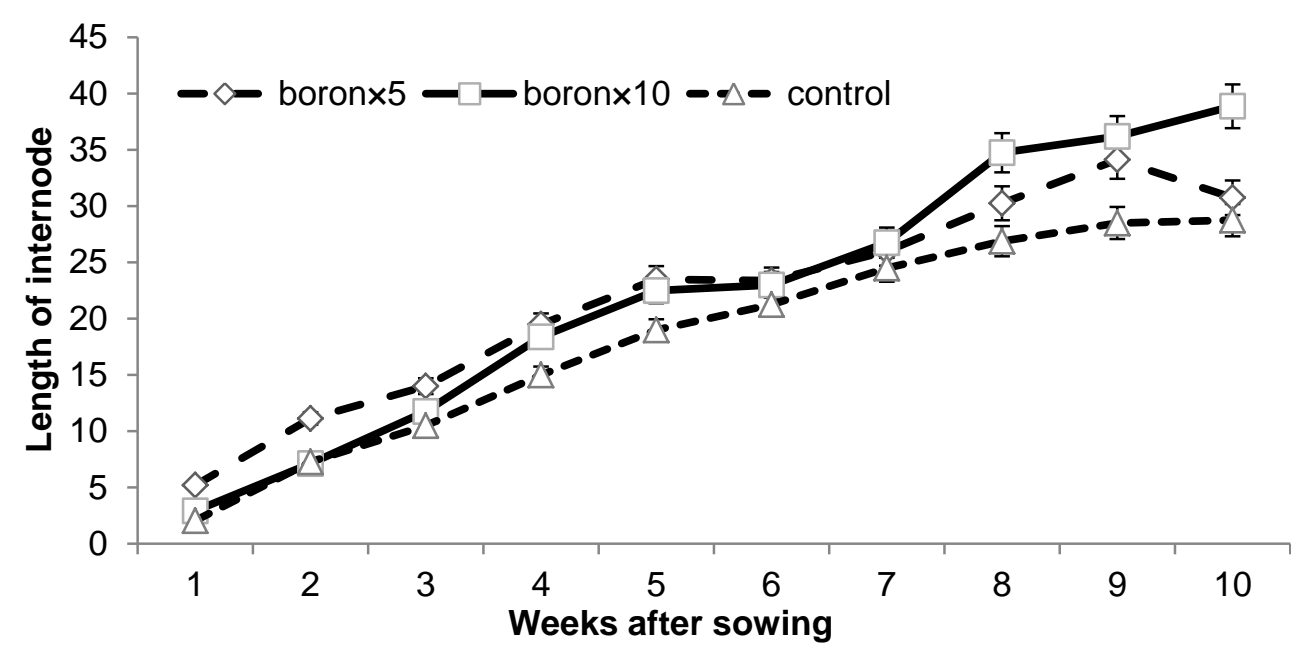

Figure 3. Effect of different levels of boric acid on the length of internode of tomato. [Boric acid $x 5=$ Boric acid increase by a factor of 5; Boric acid conc. $=0.00154 \mathrm{~g} \mathrm{l}^{-1}$; Boric acid $\times 10=$ Boric acid increase by a factor of 10 ; Boric acid conc. $=0.00308 \mathrm{~g} \mathrm{l}^{-1}$; Control $=$ Normal nutrient solution; Boric acid conc. $=0.000308 \mathrm{~g} \mathrm{l}^{-1}$ ]

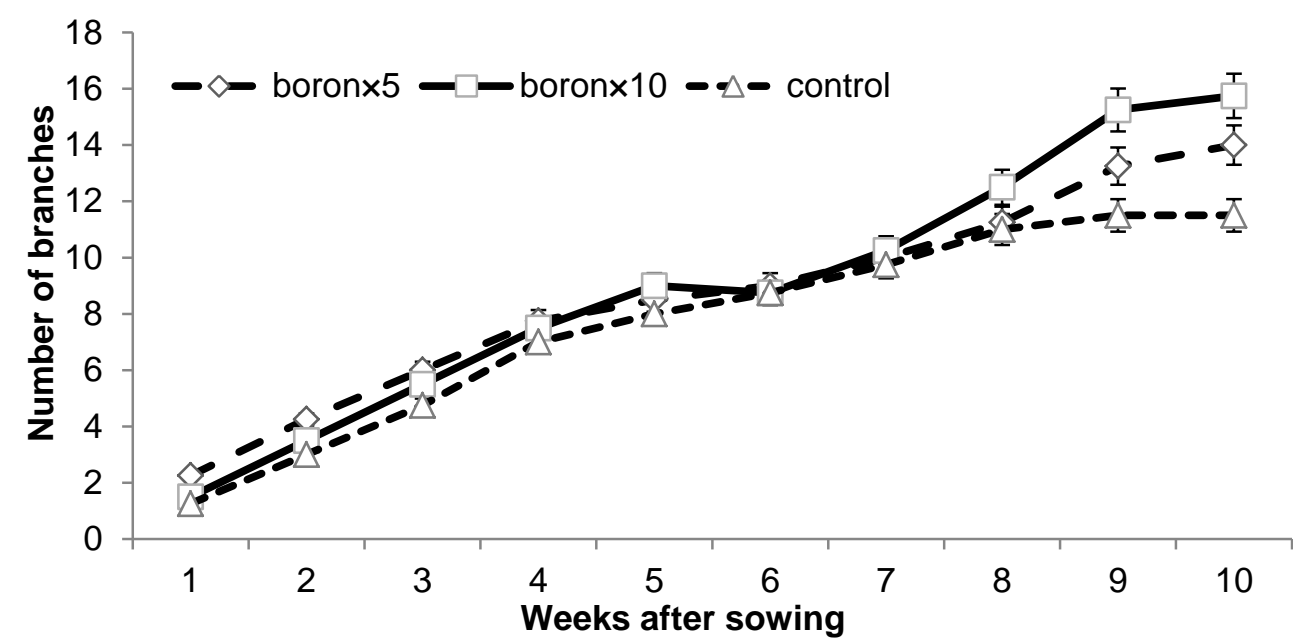

Figure 4. Effect of different levels of boric acid on the number of branches of tomato. [Boric acid $\mathrm{x} 5=$ Boric acid increase by a factor of 5; Boric acid conc. $=0.00154 \mathrm{~g} \mathrm{l}^{-1}$; Boric acid $\mathrm{x} 10=$ Boric acid increase by a factor of 10 ; Boric acid conc. $=0.00308 \mathrm{~g} \mathrm{l}^{-1}$; Control $=$ Normal nutrient solution; Boric acid conc. $\left.=0.000308 \mathrm{~g}^{-1}\right]$

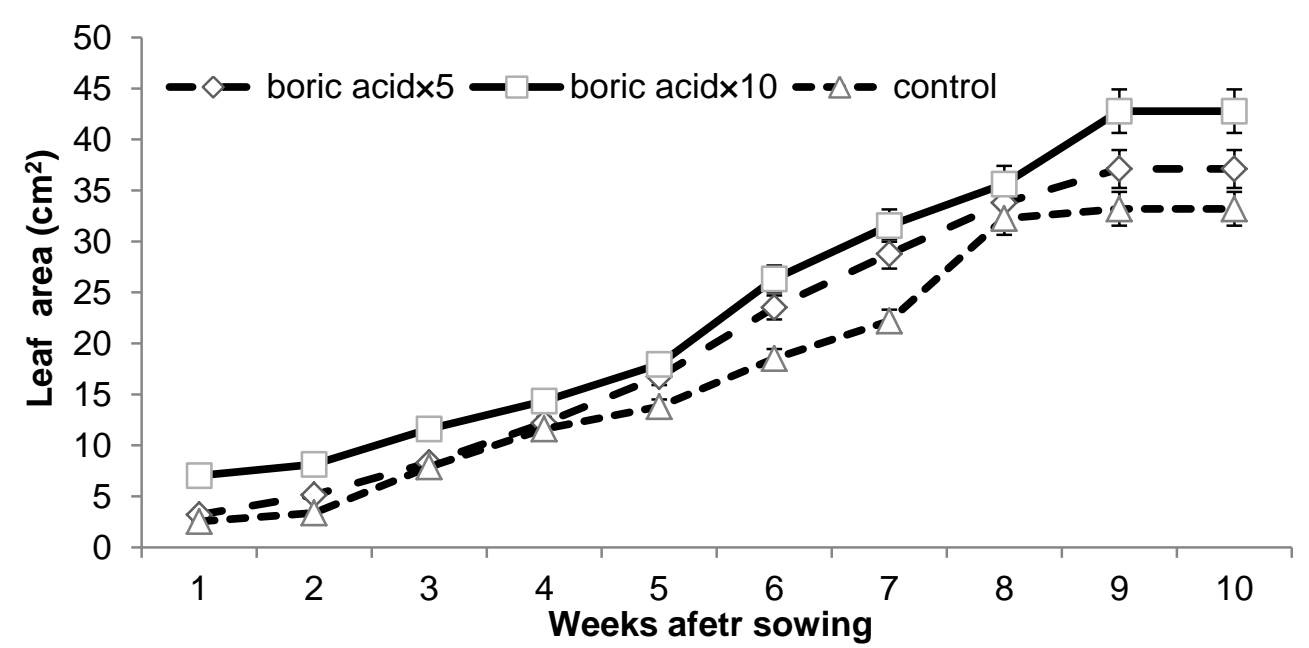

Figure 5. Effect of different levels of boric acid on the leaf area of tomato. [Boric acid $\mathrm{x} 5=$ Boric acid increase by a factor of 5 ; Boric acid conc. $=0.00154 \mathrm{~g} \mathrm{l}^{-1}$; Boric acid $\times 10=$ Boric acid increase by a factor of 10 ; Boric acid conc. $=0.00308 \mathrm{~g} \mathrm{l}^{-1}$; Control $=$ Normal nutrient solution; Boric acid conc. $=0.000308 \mathrm{~g} \mathrm{l}^{-1}$ ] 


\section{Growth indices}

Crop growth rate (CGR), relative growth rate (RGR), net assimilation rate (NAR) of plants made to receive boric acid increased by the factor of 10 was the highest and control was the lowest. Plants supplied with boric acid increased by a factor of 10 also had the highest leaf area ratio (LAR) and tissue water content (TWC) and the control was the lowest. There was significant difference in the Crop Growth Rate (CGR), Relative Growth Rate (RGR), Net Assimilation Rate (NAR), leaf area ratio (LAR) and tissue water content (TWC) among the treatments at $p \leq 0.05$ (Table 2).

Table 2. Effect of different levels of boric acid on the growth indices of tomato.

\begin{tabular}{lrrrrr}
\hline Treatments & CGR & RGR & NAR & LAR & TWC \\
\hline boric acid x5 & $7.32+0.01^{\mathrm{b}}$ & $0.325+0.03^{\mathrm{b}}$ & $0.0344+0.01^{\mathrm{b}}$ & $9.447+0.02^{\mathrm{b}}$ & $31.8+0.01^{\mathrm{b}}$ \\
boric acid x10 & $19.78+0.04^{\mathrm{a}}$ & $0.617+0.00^{\mathrm{a}}$ & $0.0696+0.02^{\mathrm{a}}$ & $48.96+0.03^{\mathrm{a}}$ & $53.8+0.01^{\mathrm{a}}$ \\
Control & $6.23+0.01^{\mathrm{c}}$ & $0.267+0.01^{\mathrm{c}}$ & $0.0126+0.05^{\mathrm{c}}$ & $3.839+0.01^{\mathrm{c}}$ & $22.67+0.01^{\mathrm{c}}$ \\
\hline
\end{tabular}

Note: Values with the same superscript along the same column are not significantly different at $\mathrm{P} \leq 0.05$; CGR $=$ Crop growth rate; $\mathrm{RGR}=$ Relative growth rate; NAR $=$ Net association rate; $\mathrm{LAR}=$ Leaf area ratio; $\mathrm{TWC}=$ Tissue water content; Boric acid $\mathrm{x} 5=$ Boric acid increase by a factor of 5; Boric acid conc. $=0.00154 \mathrm{~g} \mathrm{l}^{-1}$; Boric acid x $10=$ Boric acid increase by a factor of 10 ; Boric acid conc. $=0.00308 \mathrm{~g} \mathrm{l}^{-1} ;$ Control $=$ Normal nutrient solution; Boric acid conc. $=0.000308 \mathrm{~g} \mathrm{l}^{-1}$

\section{Plant biomass}

The boric acid $\times 10$ treatment had the highest root, shoot, leaf and total fresh weight followed by the boric acid $\times 5$ treatment and the control was the lowest (Fig. 6). Treatment also affected the dry weight (Fig. 7). The iron $\times 10$ treatment had the root, shoot, leaf and total dry weight followed by the boric acid $\times 5$ treatment and the control.

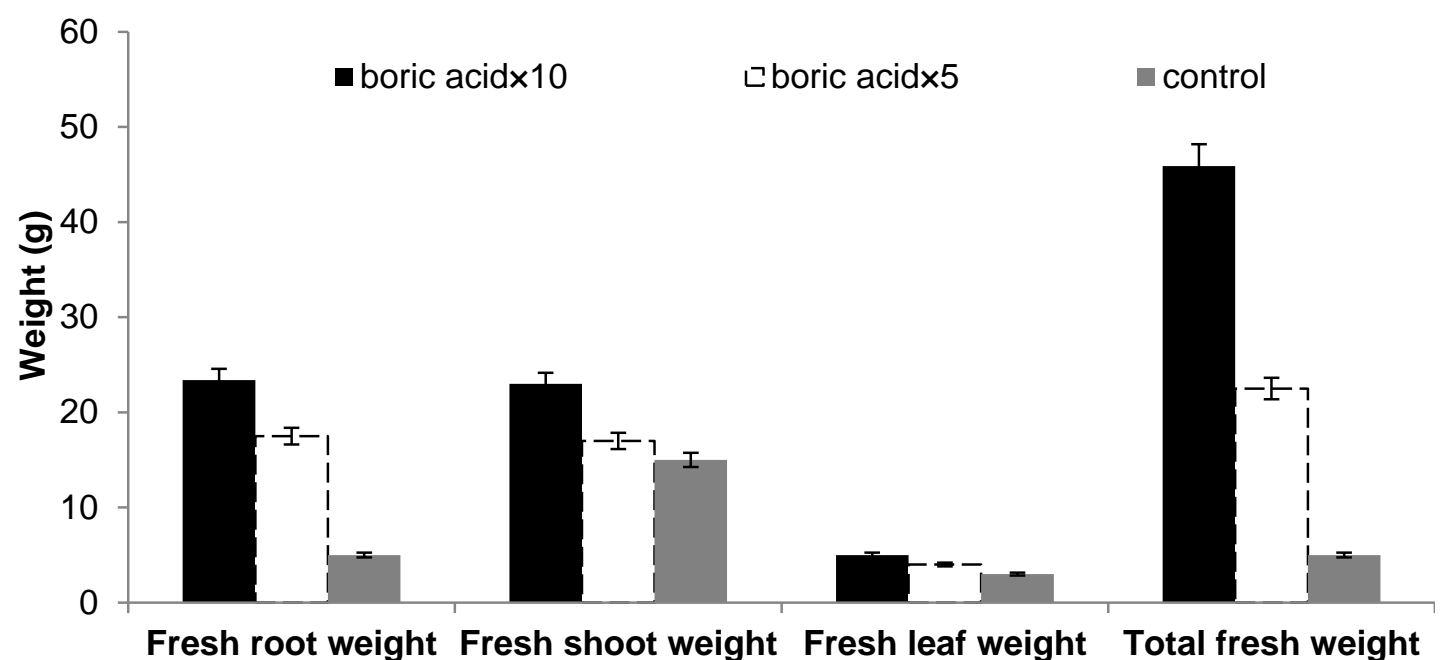

Figure 6. Effect of different levels of boric acid on the fresh weight of tomato. [Boric acid $\mathrm{x} 5=$ Boric acid increase by a factor of 5; Boric acid conc. $=0.00154 \mathrm{~g} \mathrm{l}^{-1}$; Boric acid $\mathrm{x} 10=$ Boric acid increase by a factor of 10 ; Boric acid conc. $=0.00308 \mathrm{~g} \mathrm{l}^{-1} ;$ Control $=$ Normal nutrient solution; Boric acid conc. $=0.000308 \mathrm{~g} \mathrm{l}^{-1}$ ]

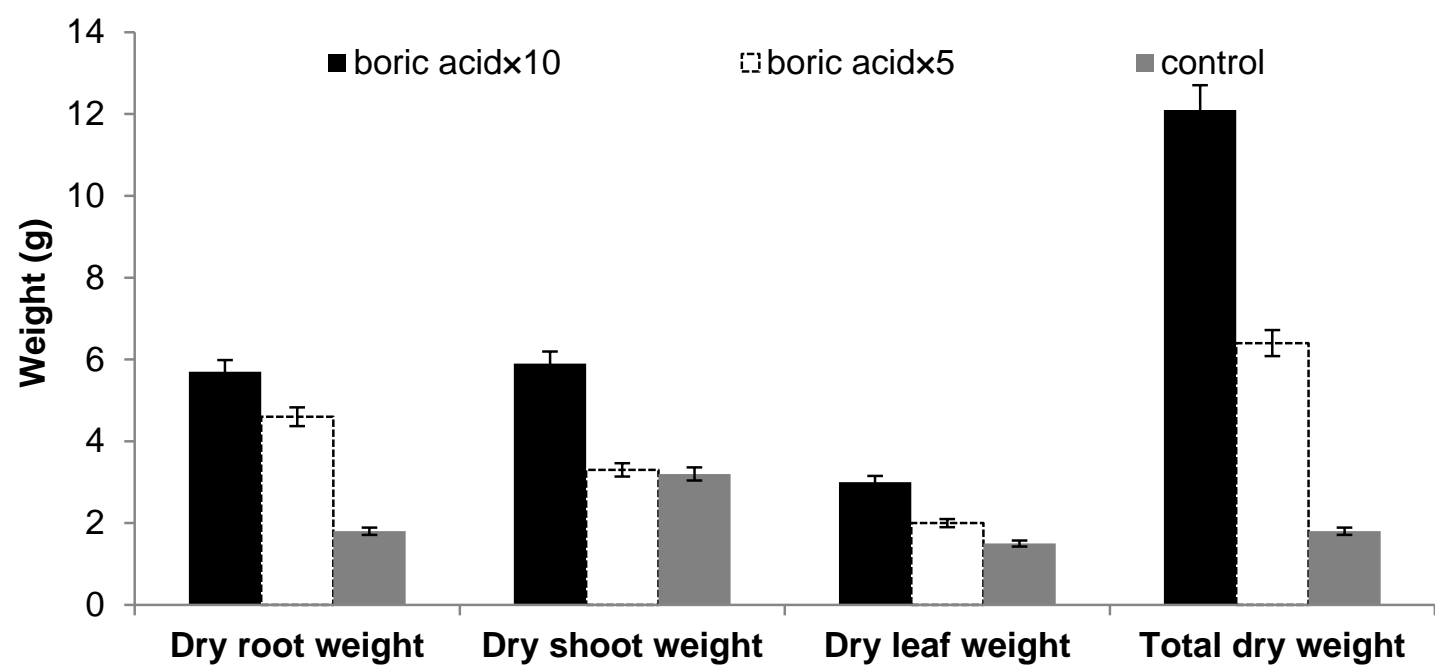

Figure 7. Effect of different levels of boric acid on the dry weight of tomato. [Boric acid $\mathrm{x} 5=$ Boric acid increase by a factor of 5 ; Boric acid conc. $=0.00154 \mathrm{~g} \mathrm{l}^{-1}$; Boric acid $\mathrm{x} 10=$ Boric acid increase by a factor of 10 ; Boric acid conc. $=0.00308 \mathrm{~g} \mathrm{l}^{-1} ;$ Control $=$ Normal nutrient solution; Boric acid conc. $=0.000308 \mathrm{~g} \mathrm{l}^{-1}$ ] 


\section{DISCUSSION}

The higher shoot height, number of leaves, length of internodes, number of branches and leaf area, in plants supplied with boric acid increased by a factor of 10 was due to subsequent buildup of assimilates. This positive effect of boric acid on the growth may relate to the role of boron in enzymatic processes, cell division and expansion activation (Marschner, 1995).

The higher fresh and dry plant weight observed in plant with boric acid increased by a factor of 10 can be attributed to the role of boron in sugar synthesis and starch translocation. Sugar synthesis and starch translocation has been shown as one of the processes involved in the fresh and dry matter accumulation. This is evident on the higher CGR, NAR, LAR and TWC observed in plants made to receive boric acid increased by a factor of 10 .

\section{CONCLUSION}

The results obtained from this study showed that morphological parameters, growth indices and plant biomass of tomato were greatly enhanced by high concentration of boric acid. Therefore, it can be concluded that boron at high concentration is effective in improving growth and plant biomass of tomato.

\section{ACKNOWLEDGMENTS}

Authors thank Professor A. A. Adelusi for his fatherly role and advise to this field work.

\section{REFERENCES}

El-Sharkawy G.A. \& Abdel-Razzak H.S. (2010). Response of cabbage plants (Brassica oleraceae var. capitata L.) to fertilization with chicken manure, mineral nitrogen fertilizer and humic acid. Alex Science Exchange Journal, 31: 416-432.

Marschner H. (1995). Functions of Mineral Nutrients Micronutrients. In: Mineral Nutrition of Higher Plants, $2^{\text {nd }}$ Ed. Academic Press, London.

Naz R.M.M., Muhammad S., Hamid A. \& Bibi F. (2012). Effect of boron on the flowering and fruiting of tomato. Sarhad Journal of Agriculture, 28(1): 37-40.

Olowolaju E.D. \& Adelusi A.A. (2017). Photosynthetic Pigments Accumulation and Some Growth Indices of Cowpea, Maize and Tomato in Response to Interspecific and Intraspecific Competition Stress. Science in Cold and Arid Region, 9(2): 1-6.

Oyinlola E. \& Chude V. (2004). Response of irrigated tomato to Boron fertilizer its: Yield and quallity. Nigerian Journal of Soil and Environmental Research, 5: 53-61.

Prasad K.K., Chaudhary B.M., Amrendra K. \& Kumat A. (1997). Response of tomato to boron application in Chotanagpur region. Journal of Research, 9(2): 145-147.

Türkmen Ö., Dursun A., Turan M. \& Erdinç Ç. (2004). Calcium and Humic Acid Affect Seed Germination, Growth and Nutrient Content of Tomato (Lycopersicon esculentum L.) Seedlings under Saline Soil Conditions. Soil Plant and Science, 54 : $168-174$. 